\title{
Fire in Medium Fuels of West Texas
}

\section{ALAN L. HEIRMAN AND HENRY A. WRIGHT}

Highlight: Chained and unchained mesquite in medium fuels were burned to measure the effect of prescribed burning on noxious brush species and on the production and utilization of major forage species. The fire did not kill any living mesquite trees. Very few standing dead mesquite stems burned down. Chained mesquite stems were easily consumed by fire with 2,000 lb/acre of fine fuel. Pricklypear and cholla mortality exceeded $50 \%$ by the end of the second growing season. Burning greatly increased production and utilization of tobosa grass; production of buffalograss was unaffected. Most annual forbs were harmed by burning.

Fire has the potential to burn down and kill honey mesquite (Prosopis glandulosa var. glandulosa) in heavy fuel types $(4,000$ to $7,000 \mathrm{lb} / \mathrm{acre})$ in west Texas (Britton and Wright, 1971), but knowledge concerning the effects of fire in light to moderate fuels $(1,000$ to 4,000 $\mathrm{lb} / \mathrm{acre}$ of fine fuel) is lacking. This study was designed to measurc: 1) the effect of planned burning on the mortality of mesquite, cholla (Opuntia imbricata), and pricklypear (Opuntia phaeacantha); 2) the burndown of standing mesquite trees previously top-killed by aerial spraying; 3 ) the percent consumption by fire of mesquite logs previously chained; 4) the effects of burning on the composition and production of a High Plains grass

The authors are research assistant and associate professor of range management, Texas Tech University, Lubbock. The senior author is at present range conservationist, Soil Conservation Service, Little Rock, Arkansas.

The research is College of Agricultural Sciences Contribution number T-9-110, Texas Tech University, Lubbock.

Manuscript received September 14, 1972. community; and 5) the utilization of tobosa (Hilaria mutica) and buffalograss (Buchloe dactyloides) in burned and unburned plant communities.

Mesquite trees are relatively tolerant of fires, although some usually die after fires, especially if they are young (Glendening and Paulsen, 1955; Cable, 1961). Glendening and Paulsen (1955) reported that summer fires killed $52 \%$ of the young velvet mesquite (Prosopis velutina) that were 0.5 inches or less in basal stem diameter. However, after mesquite trees develop beyond the "young" stage, they are very difficult to kill. Only 8 to $15 \%$ of the velvet mesquite trees larger than 0.5 inches are killed by summer fires, although the percentage of those top-killed varies from 62 to $99 \%$ (Glendening and Paulsen, 1955). If the trees have been top-killed before burning, mortality of honey mesquite has varied from 0 to $32 \%$ after the first growing season (Stinson and Wright, 1969; Britton and Wright, 1971).

Cleaning up dead brush is another asset from prescribed burning. Britton and Wright (1971) found that weather, fine fuel, diameter of trees, surface characteristics, and borer activity influenced percent of dead mesquite stems that burned down. Relative humidity, wind, and fine fuel accounted for $86 \%$ of the variation. Burndown increased from $38 \%$ for 2 -inch trees to $67 \%$ for 5 -inch or larger trees.

Cactus plants in mesquite communities have shown considerable variability in their response to fire. In Arizona the mortality for pricklypear the first year after burning varies up to $32 \%$ (Cable, 1967). Cane cholla (Opuntia spinosior) mortality, however, is usually higher about 45\% (Cable, 1967). Cane cholla less than 1-ft tall is much more susceptible to mortality than cholla over 1-ft tall (Dwyer and Piper, 1967).

The effect of burning on grassland production varies from one area to another. Cable (1967) stated that, "fire may kill or damage individual perennial grass plants, or may indirectly increase grass growth by reducing the density of competing shrubs." Other researchers have found that burning reduced grass production for the first few years (Reynolds and Bohning, 1956; Trilica and Schuster, 1969).

Aldous (1934) studied the effects of burning on bluestem pastures in eastern 
Kansas and concluded that burning about every other year seemed to be highly desirable if not essential on bluestem pastures. Annual spring burning has been found by Curtis and Partch (1948) to be essential in the re-establishment of native prairie in southern Wisconsin. Wright (1969), reporting on the effects of burning a tobosa community during "wet" years on the plains of Texas, found that fire increased production of tobosa from 56 to $256 \%$ and decreased the yield of forbs, particularly annual broomweed Xanthocephalum dracunculoides). Moreover, utilization of coarse plants can be greatly increased following burns because the lush green growth is free from dead carry-over growth (Klett et al., 1971).

\section{Methods and Procedures}

Three-hundred acres of the PostMontgomery Estate in Lynn County, Tex. were burned with a natural headfire on March 23, 1970. The burned area had been aerially sprayed with 2,4,5-T in 1963. A 95\% top-kill was obtained with the spray, but less than $5 \%$ of the trees actually died. A portion of the sprayed area was chained in 1969, but few trees were killed by chaining. In both areas (chained and unchained) the trees were dense and had resprouts 3 to $6 \mathrm{ft}$ tall. A control area, which had also been aerially sprayed in 1963 , but not chained, was located near the burned area.

Vegetation within the study areas is dominated by nearly pure stands of tobosa and buffalograss. Mesquite, cholla, and pricklypear are dominant brush species.

Relief of the study area is level to gently undulating. Elevation ranges from 3,000 to $3,300 \mathrm{ft}$. Geographically, this area lies within the Southern High Plains. Deep hardland soils of the Amarillo loam series occupy $75 \%$ of the study area. These soils are moderate to high in fertility, surface drainage is slow, and internal drainage is medium. The average annual precipitation, which falls primarily in the spring and fall, is 19 inches.

Sixty $2.4 \mathrm{ft}^{2}$ quadrats were clipped in each of the chained, unchained, and control areas to determine the quantity of fine fuel and grass production before burning. All samples were oven-dried at $160^{\circ} \mathrm{F}$ for 24 hours and weighed.

Before burning, 150 live mesquite trees were permanently marked in each of the chained, unchained, and control areas and classified according to basal diameter: 1) less than 2 inches and 2) 2 to 6 inches. Half of the trees were randomly located in tobosa fuel and half in buffalograss fuel.

Dead mesquite stems (killed with
2,4,5- $\mathrm{T}$ in 1963) were erect in the unchained area and horizontal in the chained area, but were attached to a living basal bud zone in both cases. After the burn, mesquite stems were classed according to severity of damage: 1) mesquite stems (previously killed by 2,4,5-T) burned down and no resprouting; 2) mesquite stems burned down and resprouting; 3) and mesquite stems not burned down and resprouting. A burndown was recorded if the main trunk of the tree was still attached to the living basal bud zone and was burned in half.

Within each fuel type 20 to 30 mesquite logs, unattached to a living base, were marked in the chained area. They were classified according to diameter: 1) less than 2 inches and 2) 2 to 6 inches. The amount of fuel around each log was estimated in the buffalograss fuel type. After the burn, the percentage of each log consumed by fire was recorded in both fuel types within the chained area. A correlation was made between the amount of fuel present and the percentage of each log consumed.

Prior to burning, 120 cholla plants in each of the three treatment areas were marked and classified according to height: less than $1 \mathrm{ft}$ and greater than $1 \mathrm{ft}$. Sixty plants of each size class were within each treatment area. Half the plants in each size class were located in tobosa fuel and half in buffalograss fuel.

Before treatment, 120 pricklypear were marked within the chained, unchained, and control areas and classed according to the number of pads: 1) less than ten pads and 2) ten or more pads. Half of the plants in each size class for each area were located in the tobosa and buffalograss fuel types.

The effect of burning on species composition, production, and utilization was measured using caged plots. Paired plots, $5 \mathrm{ft}$ in diameter, were located randomly within the chained, unchained, and control areas. Ten cages were located in each tobosa and buffalograss site. Caged and uncaged plots were clipped June 19 , August 28, and November 6, 1970. After each clipping date, the cages were moved to a new sampling site. About 110 cows were stocked on 2,400 acres. During spring and fall the cattle concentrated on the burned 300 acres.

The fire of March 23, 1970, was spotty and incomplete because of insufficient fuel in some areas, especially in heavily-grazed buffalograss. The oven-dry weight of herbaceous fuel before burning averaged $1,234 \mathrm{lb} / \mathrm{acre}$ on the buffalograss area, and $4,306 \mathrm{lb} / \mathrm{acre}$ on the tobosa area. These weights included all herbaceous plant material down to the mineral soil surface.

The fire was started about 3:30 p.m. and was completed by 4:30 p.m. Maxi- mum air temperature at the time of burning was $75^{\circ} \mathrm{F}$. Winds were from the southwest, gusting from 12 to $20 \mathrm{mph}$. Relative humidity was $25 \%$ and fuel moisture of grasses was $15 \%$. Surface soil moisture was $20 \%$ and spring forbs were emerging. Rainfall received in the general area from March 1 until the day of burning ranged from 2.60 to 3.28 inches.

Maximum temperatures were taken at the soil surface with tempil cards. The average maximum soil surface temperatures for tobosa area was $460^{\circ} \mathrm{F}$ and $220^{\circ} \mathrm{F}$ for the buffalograss area.

A Chi-square analysis was used to test for mortality between treatments applied to mesquite, cholla, and prickly pear. Student's $t$-test was used to determine differences in herbage yields and utilization between caged and uncaged plots.

\section{Results and Discussion}

\section{Mesquite Mortality and Resprouts}

Most mesquite trees were top-killed but survived the burn by sprouting from the basal stem buds just below the ground surface. Height of the resprouts ranged from a few inches to over $4 \mathrm{ft} 6$ months after the burn. Rabbits, small mammals, and insects kept some resprouts low by continually feeding on them.

\section{Burndown}

A $60 \%$ burndown of dead mesquite stems burned off at base of living trees was obtained in the chained area and $6 \%$ in the unchained area (Table 1). The chained mesquite trees lying near the soil received reradiation from the soil and therefore burned more easily than the standing stems in unchained areas.

Table 1. The effect of prescribed burning on burndown of mesquite trees top-killed by aerial spraying.

\begin{tabular}{|c|c|c|c|}
\hline Treatment & $\begin{array}{c}\text { Total } \\
\text { number } \\
\text { of trees }\end{array}$ & $\begin{array}{c}\text { Number } \\
\text { burned } \\
\text { down }\end{array}$ & $\begin{array}{c}\text { Percent }^{1} \\
\text { burn- } \\
\text { down }\end{array}$ \\
\hline \multicolumn{4}{|c|}{$\begin{array}{l}\text { Chained \& burned } \\
\text { Tobosa }\end{array}$} \\
\hline $\begin{array}{r}0-2 \text { inches } \\
2-6 \text { inches } \\
\text { Buffalograss }\end{array}$ & $\begin{array}{l}13 \\
32\end{array}$ & $\begin{array}{r}9 \\
27\end{array}$ & $\begin{array}{l}69 \mathrm{~b} \\
84 \mathrm{a}\end{array}$ \\
\hline $\begin{array}{l}0-2 \text { inches } \\
2-6 \text { inches }\end{array}$ & $\begin{array}{l}16 \\
27\end{array}$ & $\begin{array}{r}4 \\
13\end{array}$ & $\begin{array}{l}25 \mathrm{~d} \\
48 \mathrm{c}\end{array}$ \\
\hline Total & 88 & 53 & 60 \\
\hline \multicolumn{4}{|c|}{$\begin{array}{l}\text { Unchained \& burned } \\
\text { Tobosa }\end{array}$} \\
\hline $\begin{array}{l}0-2 \text { inches } \\
2-6 \text { inches }\end{array}$ & $\begin{array}{l}31 \\
34\end{array}$ & $\begin{array}{l}2 \\
6\end{array}$ & $\begin{array}{r}6 \text { ef } \\
18 \mathrm{de}\end{array}$ \\
\hline $\begin{array}{r}\text { Buffalograss } \\
0-2 \text { inches } \\
2-6 \text { inches }\end{array}$ & $\begin{array}{l}28 \\
42\end{array}$ & $\begin{array}{l}0 \\
0\end{array}$ & $\begin{array}{l}0 \mathrm{f} \\
0 \mathrm{f}\end{array}$ \\
\hline Total & 135 & 8 & 6 \\
\hline
\end{tabular}

${ }^{1}$ Means within a column followed by the same letter are not significantly $(\mathrm{P}<0.05)$ different. 


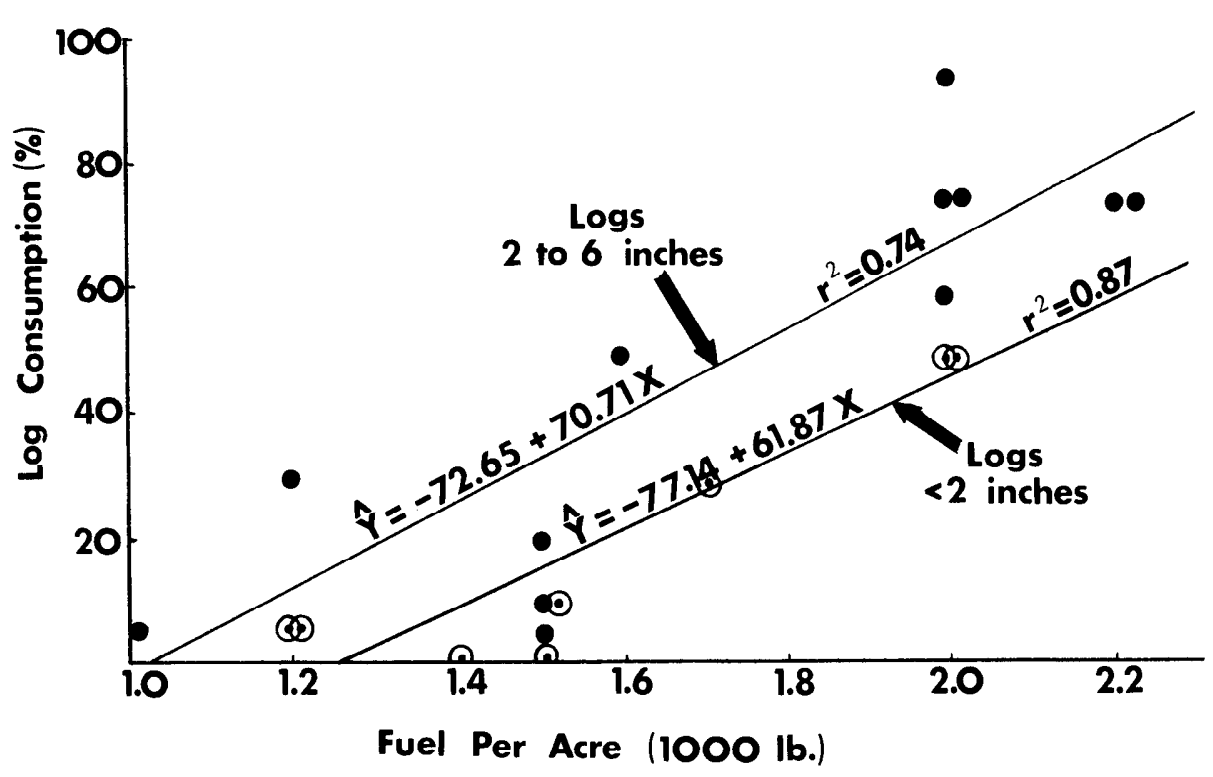

Fig. 1. Log consumption in relation to size of log and pounds of buffalograss per acre in a chained burned area.

Large trees lying near the soil surface were easier to burn than small trees, probably because the large trees received more reradiation than small trees. Also, the large trees had rough or broken bark, which gave a higher surface to volume ratio of exposed fuel than the small trees.

As a result of higher burning temperatures, the burndown of mesquite trees was higher within the tobosa fuel type than the buffalograss fuel type in both the chained and unchained areas (Table 1). Higher temperatures lower ignition time and increase burndown.

\section{Log Consumption in Chained Area}

Within the tobosa fuel, the consumption of dead stems not attached to a living base was $43 \%$ and $68 \%$ for the lessthan-2-inch and 2- to 6-inch size classes, respectively. In the buffalograss fuel $14 \%$ and $52 \% \log$ consumption occurred in the

Table 2. Percent mortality of cholla plants after a prescribed burn.

\begin{tabular}{lcc}
\hline \hline Treatment & Sept. 1970 & July 1971 \\
\hline Chained & & \\
Tobosa & & \\
$\quad$ Less 1-ft & 32 & 93 \\
Over 1-ft & 20 & 80 \\
Buffalograss & & \\
$\quad$ Less 1-ft & 25 & 75 \\
$\quad$ Over 1 ft & 18 & 50 \\
Unchained & & \\
Tobosa & $33^{*}$ & $81^{*}$ \\
$\quad$ Less 1-ft & 6 & 45 \\
$\quad$ Over 1-ft & & \\
Buffalograss & $15^{*}$ & $48^{*}$ \\
$\quad$ Less 1-ft & 0 & 4 \\
Over 1-ft & 0 & 0 \\
Control &
\end{tabular}

*Different from the over 1 -ft height class at the 0.05 level of probability. area because most cholla plants over $1 \mathrm{ft}$ high were lying near the soil surface.

There was a dramatic increase in mortality of cholla the second year after the burn (Table 2). Insect activity, induced by the fire, was responsible for most of the mortality, but drought and small mammal damage were also contributing factors.

\section{Effect of Fire on Pricklypear}

First year mortalities of pricklypear plants was $40 \%$ in the chained area and $22 \%$ in the unchained area (Table 3). After the second growing season, this mortality increased to $85 \%$ and $68 \%$, respectively. No mortality occurred in the control.

A difference in pricklypear mortality between chained and unchained areas was evidenced only in the buffalograss fuels. Chaining brings all pricklypear pads in close proximity to the soil surface, thus

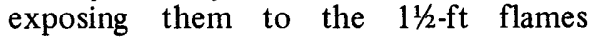
from buffalograss. Furthermore, logs and other debris in chained areas provided protection for buffalograss that ultimately generated a good fire. Thick patches of buffalograss were encountered frequently in the chained area, but not in the unchained area.

During the first growing season after burning, more pricklypear plants with fewer than 10 pads died compared with plants having 10 or more pads (Table 3 ). The higher mortality for plants with fewer than 10 pads was apparently a result of the fire's exerting maximum temperatures on all the pads, whereas the outer pads of larger pricklypear plants shielded the inner pads from maximum heat. However, there were no differences

Table 3. Percent mortality of pricklypear after a prescribed burn.

\section{Effect of Fire on Cholla}

The higher percentage of cholla plants killed by fire in tobosa grass than in buffalograss in the unchained area (Table 2) was attributed to higher temperatures. In the chained area, there was no difference in cholla mortality between the two fuel types because most of the cholla plants were lying close to the soil surface and nearly all plants were equally engulfed by flames.

In the unchained area, a higher percentage of cholla plants less than $1 \mathrm{ft}$ high were killed than those over $1 \mathrm{ft}$ high, as a

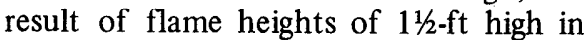
buffalograss and 4 to $6 \mathrm{ft}$ high in the tobosa grass. No differences occurred in mortality between heights in the chained

\begin{tabular}{llc}
\hline \hline Treatment & Sept. 1970 & July 1971 \\
\hline Chained & & \\
Tobosa & $50^{*}$ & 89 \\
$\quad$ Less 10 pads & 24 & 89 \\
10 or more pads & & \\
Buffalograss & $48^{*}$ & 85 \\
$\quad$ Less 10 pads & 21 & 74 \\
$\quad$ 10 or more pads & 40 & 85 \\
Average & & \\
Unchained & & \\
Tobosa & $54^{*}$ & 86 \\
$\quad$ Less 10 pads & 11 & 79 \\
10 or more pads & & \\
Buffalograss & $23^{*}$ & 53 \\
$\quad$ Less 10 pads & 6 & 53 \\
10 or more pads & 22 & 68 \\
Average & 0 & 0 \\
Control & & \\
\hline
\end{tabular}

*Different from the 10 or more pad class at the 0.05 level of probability. 
in mortality between those with more than 10 pads and those with fewer than 10 pads by the end of the second growing season.

Following the burn, numerous insects and rodents fed upon pricklypear pads. In many instances, all of the pads were removed. Following removal of the pricklypear pads, rodents sometimes excavated the root system. Furthermore, a mild drought during this study undoubtedly increased the mortality.

\section{Composition and Production}

Spring burning generally decreased the production of annual broomweed, western ragweed (Ambrosia psilostachya), and horsetail conyza (Conyza candensis) (Table 4). Warty euphorbia (Euphorbia spathulata), silverleaf nightshade (Solanum elaeagnifolium), evax (Evax multicaulis), and wooly plantago (Plantago purshii) were either not affected by burning or data were insufficient to detect significant were insufficient to detect significant differences. The only forb favored by burning was false mesquite (Hoffmanseggia densiflora). Burning can be an effective method in controlling several species of annual weeds if initiated at the proper time.

Burning increased yields of tobosa threefold, but had no effect on yields of buffalograss (Table 4). The large increase in tobosa resulted from the fire's removing large accumulations of litter that otherwise depressed tobosa production.

\section{Grass Utilization}

By June 19, 1970, 1,852 lb/acre of tobosa and $565 \mathrm{lb} /$ acre of buffalograss were utilized by cattle within the burned areas (Fig. 2). No appreciable amount of either grass species was eaten by cattle in

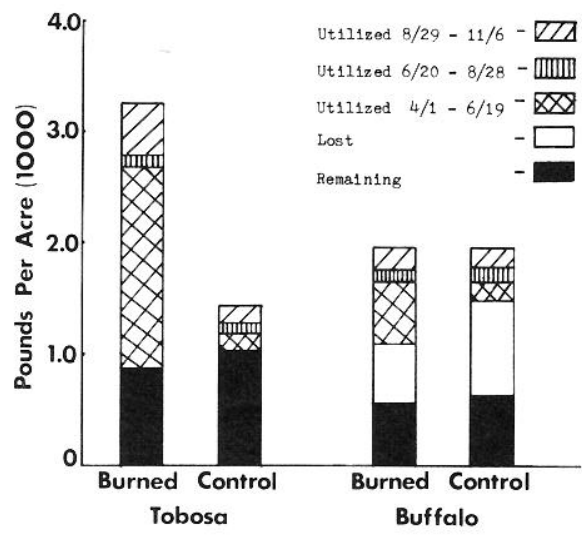

Fig. 2. Pounds of oven-dry forage produced and utilized on burned and control tobosa and buffalograss areas from April 1 to November 6, 1970 .

Table 4. Herbage yields (lb/acre) following prescribed burning.

\begin{tabular}{|c|c|c|c|c|c|c|}
\hline \multirow[b]{2}{*}{ Species } & \multicolumn{2}{|c|}{ Chained } & \multicolumn{2}{|c|}{ Unchained } & \multicolumn{2}{|c|}{ Control } \\
\hline & Tobosa & Buffalograss & Tobosa & Buffalograss & Tobosa & Buffalograss \\
\hline Grasses & 3,468 & 1,617 & 3,058 & 1,974 & 1,974 & 1,971 \\
\hline \multicolumn{7}{|l|}{ Forbs } \\
\hline False mesquite & 79 & 126 & 120 & 102 & 28 & 53 \\
\hline Broomweed & 22 & 18 & 15 & 19 & 79 & 69 \\
\hline Silver nightshade & 1 & 4 & 9 & 1 & 21 & 2 \\
\hline Warty euphorbia & 0 & 0 & 0 & 0 & 6 & 3 \\
\hline Western ragweed & 0 & 0 & 0 & 0 & 18 & 0 \\
\hline Horsetail conyza & 0 & 4 & 2 & 2 & 1 & 59 \\
\hline Evax & 0 & 0 & 0 & 0 & 2 & 3 \\
\hline Wooly plantago & 0 & 2 & 1 & 0 & 1 & 4 \\
\hline Other & 23 & 42 & 18 & 10 & 30 & 20 \\
\hline
\end{tabular}

the unburned control area.

Buffalograss was relished by cattle, but three times more tobosa was utilized. Tobosa was preferred by cattle after the burn because the unpalatable, old growth had been removed by burning and the new growth of tobosa was tender, succulent, and palatable (Fig. 3).

Rainfall was light between May and August 28; consequently, the vegetation was dry, little growth occurred, and only the chained-burned area received any significant utilization. Tobosa and buffalograss were utilized $12 \%$ to $21 \%$, respectively, in this area. Other grass species that absorbed some of the grazing pressure were blue grama (Bouteloua gracilis), Arizona cottontop (Digitaria californica), windmillgrass (Chloris verticillata), bush muhly (Muhlenbergia porteri), vine mesquite (Panicum obtusum), white tridens (Tridens albescens), and various threeawn species (Aristida spp.).

Several inches of rainfall occurred during September; the pastures greened up; and all three areas were significantly utilized during the fall (Fig. 2). Only 122 $\mathrm{lb} / \mathrm{acre}$ of tobosa was removed from the control area, whereas $431 \mathrm{lb} /$ acre was utilized in the two burned areas (Fig. 2). Consumption of buffalograss was 201 $\mathrm{lb} / \mathrm{acre}$ on the burn and $182 \mathrm{lb} / \mathrm{acre}$ on the control (Fig. 2).

When the cages were clipped in the fall, $872 \mathrm{lb} /$ acre of tobosa remained on the burned area and $1,064 \mathrm{lb} /$ acre on the unburned control; whereas $561 \mathrm{lb} /$ acre of buffalograss was present on the burn and $655 \mathrm{lb} /$ acre on the unburned control (Fig. 2). Total amount of tobosa grazed for the year was $2,388 \mathrm{lb} /$ acre on the burned area and $371 \mathrm{lb} / \mathrm{acre}$ on the control. Total amount of buffalograss grazed was $873 \mathrm{lb} / \mathrm{acre}$ on the burned

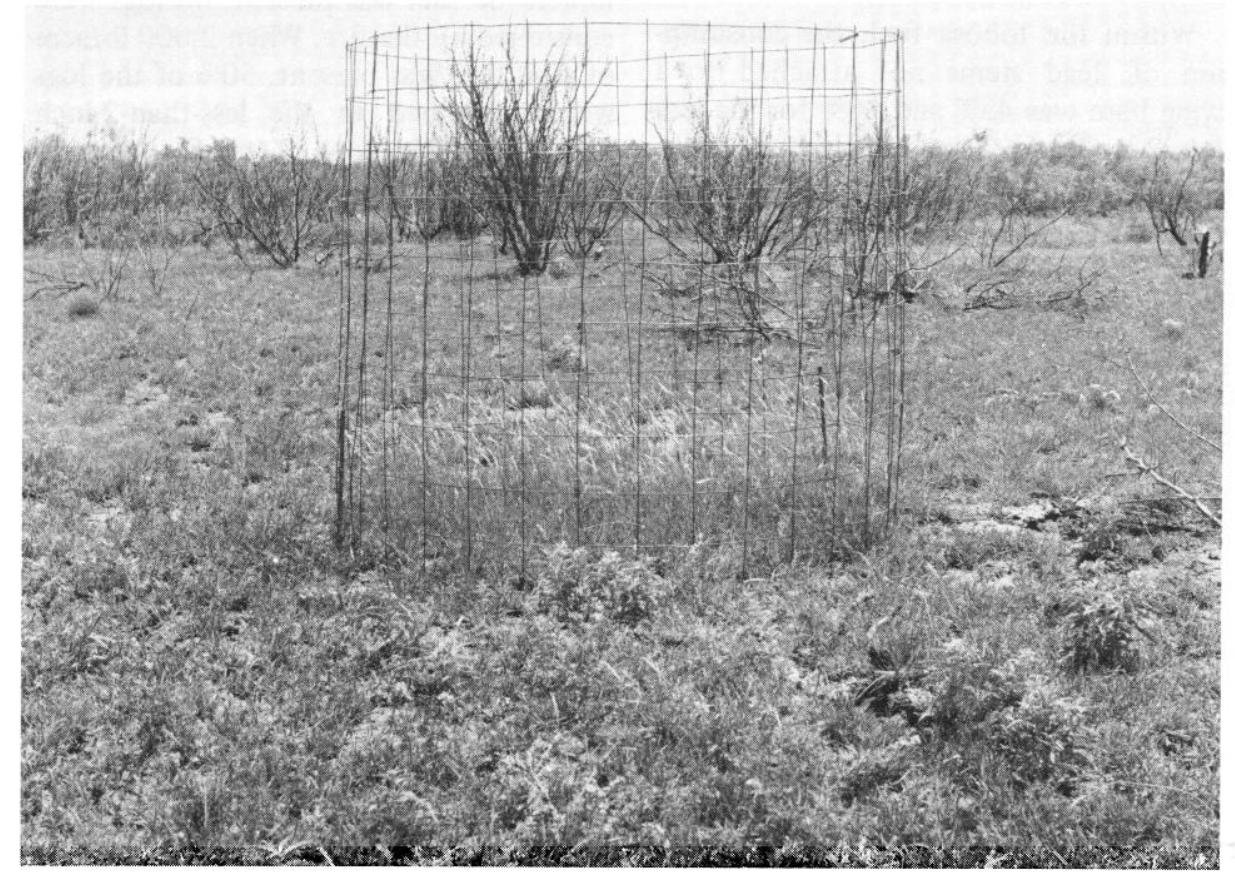

Fig. 3. Cattle preferred tobosa grass on burned areas in the spring and fall. They ate a total of $2,388 \mathrm{lb} /$ acre on the burned area compared with $371 \mathrm{lb} / \mathrm{acre}$ on the unburned area. 
area and $473 \mathrm{lb} / \mathrm{acre}$ on the control.

Between the June and August clipping dates, $539 \mathrm{lb} /$ acre of buffalograss in the burned areas and $843 \mathrm{lb} /$ acre on the control were lost (Fig. 2). Some of this loss was probably associated with the very dry summer. A portion of this loss might be attributed to oxidation, decomposition, small mammals, and particularly, termite activity. This loss should be given attention in future studies since it hardly seems logical to ask a rancher to rest his pasture during summer months only to come back in the fall to find that much of the grass "disappeared."

\section{Summary and Conclusions}

Burning did not kill any mesquite trees in moderate fuel types. When mesquite was aerially sprayed and then chained, a substantial number of dead stems were consumed by the fire. Little burndown occurred when aerially sprayed trees were standing.

Log consumption within the chained area was greater for logs in the 2-to 6-inch size class than those in the lessthan-2-inch size class. Fire consumed 50 to $75 \%$ of each $\log$ where $2,000 \mathrm{lb} /$ acre of fuel was present; but where $1,200 \mathrm{lb} / \mathrm{acre}$ of fuel was present, $\log$ consumption was negligible.
By the second year after burning, over $50 \%$ of all pricklypear plants died in all treated areas. Chaining increased mortality about $17 \%$ in light fuels. High mortality of pricklypear was due to a combination of fire, drought, insects, and small mammals.

Burning caused high mortalities in cholla. Chaining greatly increased the mortality of large chollas in tobosa grass and all chollas in buffalograss.

Burning decreased annual weeds such as broomweed, western ragweed, and horsetail conyza. Only false mesquite was definitely favored by burning.

Utilization and production of tobosa grass was increased by burning. Cattle consumed $2,016 \mathrm{lb} /$ acre more tobosa on the burned than on the control area, whereas the amount of ungrazed material remained about the same for all areas. Grazing pressure was shifted from buffalograss to tobosa during spring and fall months; thus, more buffalograss was available for summer and winter feed.

\section{Literature Cited}

Aldous, A. E. 1934. Effects of burning on Kansas bluestem pastures. Kansas Agr. Exp. Sta. Bull. 38:1-65.

Britton, C. M., and H. A. Wright. 1971. Correlation of weather variables to mesquite damage by fire. J. Range Manage. 24:136-141.

Cable, D. R. 1961. Small velvet mesquite seedlings survive burning. J. Range Manage. 14:160-161.

Cable, D. R. 1967. Fire effects on semidesert grasses and shrubs. J. Range Manage. 20: 170-176.

Curtis, J. T., and M. L. Partch. 1948. Effects of fire on the competition between bluegrass and certain prairie plants. Amer. Midl. Nat. $39: 437-443$.

Dwyer, D. D., and R. D. Pieper. 1967. Fire effects on blue grama-pinyon-juniper rangeland in New Mexico. J. Range Manage. 20:359-362.

Glendening, G. E., and H. A. Paulsen. 1955. Reproduction and establishment of velvet mesquite as related to invasion of semidesert grasslands. U.S. Dep. Agr. Tech. Bull. $1127.50 \mathrm{p}$.

Klett, E. W., D. Hollingsworth, and J. L. Schuster. 1971. Increasing utilization of weeping lovegrass by burning. J. Range Manage. 24:22-24.

Reynolds, H. G., and J. W. Bohning. 1956. Effects of burning on a desert grass-shrub range in southern Arizona. Ecology. 37:769-777.

Stinson, K. J., and H. A. Wright. 1969. Temperatures of headfires in the southern mixed prairie of Texas. J. Range Manage. 22:169-174.

Trilica, M. J., and J. L. Schuster. 1969. Effects of fire on grasses of the Texas High Plains. J. Range Manage. 22:329-334.

Wright, H. A. 1969. Effect of spring burning on tobosa grass. J. Range manage. $22: 425-427$.

\section{RANGELAND HYDROLOGY}

by Farrel A. Branson, Gerald F. Gifford, and J. Robert Owen

tells about -

Precipitation: Characteristics of rangeland precipitation

Interception, Stemflow, and Throughfall: Factors affecting interception and throughfall; Interception by woody species; Interception by herbaceous vegetation; Interception loss from litter; Other interception losses

Infiltration: Methods for measuring infiltration; Infiltration in natural rangeland plant communities; Infiltration as influenced by grazing; Effects of water repellency on infiltration; Effect of range improvement practices on infiltration

Runoff: Rangeland runoff studies from natural plant communities; Influence of grazing on runoff; Vegetation conversion effects on runoff; Water harvesting; Influence of cryptogam species on runoff; Runoff estimate methods

Erosion and Sedimentation: Sediment transport; Effects of soils on erodibility; Erosion con trol problems in rangeland environments; Effects of grazing; Influence of wetting agents; Erosion control structures and mechanical land treatments; Chemical quality of surface water
Geomorphology: Relief ratio; Drainage density; Circularity ratio; Angle of junction; Mean slope

Evaporation and Transpiration: ET measurements in rangeland environments

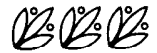

\author{
SRM Range Science Series No. 1 \\ viii +84 p. Illus. $\$ 1.75$, postpaid* \\ Society for Range Management, 2120 South Birch St., \\ Denver, Colorado 80222
}

\footnotetext{
* Special bulk order prices available to university departments or bookstores. Write to above address for information.
} 